\title{
Strategy to strengthen the national identity of millennial generation in the digital era in Indonesia
}

\author{
A A Candra ${ }^{1}$, K Suryadi ${ }^{2}$, Rahmat ${ }^{3}$, S Nurbayani $^{4}$ \\ 1,2,3,4 Indonesian University of Education, Bandung \\ 1alifadityacandra@student.upi.edu, ${ }^{2}$ karimsuryadi@upi.edu,${ }^{3}$ rahmat003@upi.edu, \\ ㄴ.nurbayani@upi.edu@upi.edu.
}

\begin{abstract}
This study aims to uncover the strategy of strengthening the national values of millennial generation in the digital era in Indonesia, this is certainly related to the importance of national values in the digital age, for this research is related to how the role of young citizens in maintaining Indonesian values has been well embedded so that it becomes the power in the form of ideology and cultural values. This study uses a qualitative approach with the critical discourse analysis method; this study uses literature reviews from the latest scientific books and leading international journal papers, so as to produce a pattern of strengthening national identity in millennials with awareness of Indonesian values and ideology of Pancasila through digital infrastructure of citizenship
\end{abstract}

Keywords: Millennial generation, Nationality, digital era

\section{INTRODUCTION}

The national identity in the area of disruption is currently full of challenges because nowadays the digital era is where communication and interaction is mostly done through the internet, thus affecting the access to information obtained. Therefore young people in a country are heavily influenced continuously by people outside their countries to shape their identity by integrating various cultures related to the homeland so that they build a flexible identity from a fixed identity to an unspecified identity [1]. Even in some countries intensifying the development of their national identity by strengthening the cultural sector, of course with a different approach, namely by deepening the knowledge and experience of the nation's culture through various development platforms for cultural education [2].

Although national identity is seen as a field that requires change and contestation, because national identity is born in the land and develops with changing times in accordance with the culture of the community in the region [3]. For this reason, national identity is defined as a new form of political organization that does not have a dependency on ethnic inheritance so it refers more to the concept of modern dynamics [4]. So as a good citizen is based on national identity despite being a person who has a global or cosmopolitan identity [5].

For this reason, this study aims to make national identity a strength in the development of selfidentity, by understanding themselves as citizens, so that citizens as individuals who mature in 
understanding and knowledge can carry out activities related to strengthening good ideologies around controversial issues, social, economic which can silence and delegitimize certain views or identities by strengthening practices and relationships with fellow citizens [6]. So culture and language become the most important part in the concept of building national identity in the current era, because culture is interpreted as a means of unifying the nation as the strength of its identity [7].

The impact of globalization makes the country's ability to produce a national identity less than the maximum, but on the one hand with the current globalization of the country has an effective means of achieving the homogeneity of its citizens, namely by strengthening the cultural value of its citizens by monopolizing the media and then incorporating elements of the nation's culture and country, the country's impact produce a single national identity that is transformed under the current of globalization [8]. If citizens are ignored without intermediaries so that they can blend in with ideas and practices that conflict with their national identity, then the global influence will gradually give a signal space so that it will cause a dangerous impact, especially for young citizens who are fingering foreign ideas so they can turn around the narrative of the future, where the hopes of the nation and country are on their shoulders to respond to this fear. Therefore it is necessary to strengthen the pattern of discourse given to young citizens through several approaches that are very close to them.

\section{RESEARCH METHOD}

This study uses a qualitative approach with critical discourse analysis methods; this study uses literature reviews from the latest scientific books and leading international journal papers relating to millennial generation, national identity, and the digital era. So that it can support and become a reference for this article.

\section{RESULTS AND DISCUSSION}

Development and dissemination of the concept of national identity is done by creating and spreading a set of symbols and rituals so as to strengthen a sense of community among citizens, this is useful for creating common enemies and progressive consolidation including national education and the media system [8]. So that the same system of values (culture) create the same national culture in shaping national identity [9].

The fact shows that this digital diera, which can enhance national identity is in the form of cultural identity, so citizens are not as objects of cultural influence but can reject or integrate or promote their culture, for that with the development of technology, individuals become closer so there is a sense of togetherness and have a sense of caring about the uniqueness and distinctiveness of their own culture, so that culture can provide global significance, local knowledge and a sense of belonging to the nation [10]. In order to analyze the national identity that needs to be reviewed is about the production of its culture and also the existence of its design so as to form a national character, this is important because it will be the power to shape the actions of citizens [11]. 
There are four patterns of shifting national identity that are viewed from the perspective of cultural acceptance including affirmative, subtractive, additive, and global, affirmactive. It can be said as a citizen who has the strongest tendency in maintaining the substrative national cultural identity, that is someone who is too dominant towards cultural identity to a foreigner than his own nation, additives have a high power influence on foreign culture so that it has difficulty in identifying the culture of his own nation. Whereas the global emphasis is more on the identity of the global community which it follows but is low in cultural knowledge of its people [12].

So that in several approaches, things that can be done in promoting national identity include the Civic engagement, Cultural, Dialogue, Decentralization, and Building inclusive institutions approaches [13]. But as a psychological construction, culture is a system of making meaning together. This is transmitted across generations. As a system of making meaning, culture consists of narrative or group history. It is also based on specific ontologies (understanding of the nature of reality), epistemological (ways of knowing reality and truth), axiological (standard values), and teleological orientation (goals). Culture determines the roles and norms of behavior, communication patterns, and effectiveness generally accepted.

Identity is sensation and self perception. Together, cultural identity can be considered as a sensation and one's perception of oneself as informed by the integrated historical, ontological, epistemological, axiological, and teleological meaning systems. The study of cultural identity is multidisciplinary and interdisciplinary, rooted in social / personality psychology, micrososiology, and anthropology. In psychology, researchers mainly focus on the relationship between and among positive psychological outcome indicators such as academic achievement, endurance, self-esteem, morality, subjective well-being, therapeutic satisfaction, and the seven core elements of cultural identity: (1) cultural self-categorization, (2) cultural narratives, (3) the centrality of cultural identity, (4) the importance of cultural identity, (5) the role of culture, (6) the enactment of cultural roles, and (7) cultural matters of society are considered personal and cultural [14].

Thus, on one side, national identity plays an important role in shaping one's personality by way of acculturation in daily life [15]. And also cultural differences can also understand each other or acculturate is part of the business [16]. So that the culture of each nation has a very important role in shaping and developing its human potential for that national identity is always the foundation of every behavior of its citizens, because each nation has culturally distinct individuals so that national identity is seen as the cultural collectivity of each of its citizens [15]. The values of a national identity for a country are the values needed for unity and the existence of a country and the values of this national identity function as a symbol of its existence in the world. For this reason, the social values found in the community are never in conflict with national identity, but rather are mutually constructive to the prevailing social values and norm systems [17]. As with the way the promotion of national values in the Astana example can have a significant impact on increasing traditional values both traditionally and innovatively [18] [19].

\section{CONCLUSIONS}


The strategy in strengthening national values (national identity) for millennial generation is to strengthen the cultural values of the nation as a product of the ancestral products of the Indonesian people, but in transmitting into the substance of millennial generation must be a massive approach but very attached to millennial generation is a technological approach that millennial generation is very responsive to on a daily basis, so that it does not only provide information but also education that is elegant and enjoyable. Next is to embed the ideology of Pancasila by providing stimulus through technological media in the form of the values of struggle, love for the motherland, and the spirit of unity, so that as a millennial generation, they will consciously emerge a sense of belonging to their nation and state and love of the nation Indonesia will become more optimal.

\section{REFERENCES}

[1] E. Caneva, "Identity processes in the global era : the case of young immigrants living in Italy immigrants living in Italy," J. Youth Stud. ISSN, vol. 6261, no. May, 2016.

[2] D. Long, "Construction of National Identity of Ritual Culture- based College Students," 2018, vol. 205, no. Iccese, pp. 1322-1325.

[3] R. R. Premdas, "Identity, ethnicity, and the Caribbean homeland in an era of globalization," Soc. Identities, vol. 17, no. 6, pp. 811-833, 2011.

[4] A. j. Bellamy, The formation of Croatian national identity. Manchester and New York: Manchester University Press, 2018.

[5] D. Sindic, "Psychological Citizenship and National Identity," J. Community Appl. Soc. Psychol., vol. 21, pp. 202-214, 2011.

[6] N. Zealand, "Constructions of national identity and the nation : the," The Open University, 1997.

[7] Y. Gesisli, "The Development Study Of National Identity Perception Scale," Int. J. New Trends Educ. Their Implic., vol. 5, no. 4, pp. 1-11, 2014.

[8] M. Guibernau, "Nation Formation and National Identity," The Open University, 2004.

[9] F. U. Husamettin Inac, "The Construction of National Identity in Modern Times: Theoretical Perspective,” Int. J. Humanit. Soc. Sci., vol. 3, no. 11, pp. 223-232, 2013.

[10] Y. Wang, "Globalization Enhances Cultural Identity," Intercult. Commun. Stud., vol. XVI, no. 1, pp. 83-86, 2007.

[11] J. Choi, "K-Design: the New Design Vision for the New Korean Government," in 1, 2014, no. December 2012, pp. 593-597.

[12] S. Tambyah, R. Chng, C. Experiencessiok, K. Tambyah, S. Tambyah, and L. Price, "Revisiting the Cultural Identity Model : Sojourners ' Negotiations of Identity and," Association For Consumer Research, vol. 33, Minnesota, pp. 464-465, 2006.

[13] S. Herbert, "Promoting national identities," Applied Knowledge Services, vol. 1, Birmingham, pp. 1-13, 2013.

[14] C. L. M. Lipner, R. Mendelsohn, and J. C. Muran, "The SAGE Encyclopedia of Abnormal and Clinical Psychology Psychoanalysis," in Sage Reference, Psychoanal., A. Wenzel, Ed. Thousand Oaks: SAGE Publications, Inc., 2017, pp. 2709-2711.

[15] C. Papademetriou, "National Culture Underpins Individual Behaviour and WorkRelated-Values: The importance of nationality," Sch. Econ. Sci. Bus., vol. 1, no. 2, pp. $1-16,2014$.

[16] G. L. Marija Nikolic, Maura, "National Culture Values : Reflections on Formation Process of Future Leaders in International Economic Cooperation," J. Educ. Cult. 
Soc., vol. 2, no. 2, pp. 217-226, 2013.

[17] M. Türkkahraman, "Social Values and Value Education," Procedia - Soc. Behav. Sci., vol. 116, pp. 633-638, 2014.

[18] G. Tursyn, K. Aktolkyn, S. Gulmira, and Z. Dinara, "National Culture : Tradition and Innovation (On the Basis of Semiotic Analysis of Kazakhstan's Capital)," Procedia Soc. Behav. Sci., vol. 81, pp. 32-39, 2013.

[19] K. Saddhono, "Integrating Culture in Indonesian Language Learning for Foreign Speakers at Indonesian Universities." J. of Lang. and Lit. vol. 6 no.2 pp. 349-353, 2015 